\title{
An Unknown Best-Seller: The Confessionario of Girolamo da Palermo
}

\author{
Rosa Marisa Borraccini
}

This study is based on bibliographical evidence that has emerged from the book inventories of the libraries of Italian religious Orders generated by enquiries carried out at the request of the Congregation of the Index of Prohibited Books between 1597 and 1603. This survey was instituted by the censors to verify the orthodoxy of the works being read by members of the Italian religious communities at a time when the Catholic Reform was having its maximum impact. The unintended result has been to provide an unrivalled vision of the books collected in the convents and monasteries that were home to members of the regular Italian Orders, and to a number of lay brothers and nuns who were within the spiritual and territorial jurisdiction of these Orders. In 1913 the library lists, which had been kept in the Congregation archive, were all transferred - following the suppression of the archive - to the Vatican Library where they now constitute Vaticani Latini Codices 11266-11326. ${ }^{2}$ The corpus has been studied for many years as part of the research project into the enquiry by the Congregation of the Index (RICI). The joint efforts of several scholars involved in the RICI has produced a substantial collection of studies and a database, now since 2013 publicly available through the servers of the Vatican Library. ${ }^{3}$ This digital resource permits the rediscovery of works that are

1 Roberto Rusconi, 'Le biblioteche degli Ordini religiosi in Italia intorno all'anno 1600 attraverso l'inchiesta della Congregazione dell'Indice', in Edoardo Barbieri and Danilo Zardin (eds.), Libri, biblioteche e cultura nell'Italia del Cinque e Seicento (Milan: Vita e Pensiero, 2002), pp. 63-84; Rosa Marisa Borraccini and Roberto Rusconi (eds.), Libri, biblioteche e cultura degli Ordini regolari nell'Italia moderna attraverso la documentazione della Congregazione dell'Indice. Atti del Convegno Internazionale (Macerata 30 maggio - 1 giugno 2006) (Vatican: Biblioteca Apostolica Vaticana, 2006), especially Gigliola Fragnito, 'L'Indice clementino e le biblioteche degli Ordini religiosi', pp. 37-59. All online resources quoted in this article were last consulted on 30 June 2015 .

2 Marie-Madeleine Lebreton and Luigi Fiorani, Codices Vaticani Latini. Codices 11266-11326. Inventari di biblioteche religiose italiane alla fine del Cinquecento (Vatican: Biblioteca Apostolica Vaticana, 1985).

3 The database, still in progress, is available at <http://rici.vatlib.it/>. See Rosa Marisa Borraccini, Giovanna Granata and Roberto Rusconi, 'A proposito dell'Inchiesta della 
otherwise totally unknown today because all surviving copies have disappeared. This work has confirmed the pioneering intuition of Romeo De Maio who, in 1973, pointed to the Vatican corpus as an extraordinarily valuable contribution towards a more comprehensive knowledge of publishing output in the fifteenth and sixteenth centuries. ${ }^{4}$

A very significant case that can be followed through the RICI archive is the Confessionario by the Dominican theologian Girolamo da Palermo, a figure who today is altogether unknown, but who in his time was renowned for his piety and doctrine. Born in Palermo, he studied and made his profession of faith in 1514 in Naples, in the Convent of Santa Caterina a Formello. As a Master of Sacred Theology he lectured at the Studia of Naples and Bologna, and shunned the honours and high ecclesiastical office of the episcopal appointment offered to him by Pope Paul IV. The sources restore to him an image of a 'Regularis observantiae cultor eximius, et paupertatis sedulus custos' [Staunch defender of the Franciscan spirit and assiduous lover of poverty]. He died in Naples in 1595 and the process for his beatification began in $1670 .{ }^{5}$

Only two works by him are known: the Confessionario and the Catechismus catholicus. The latter, to date, only survives in a very limited number of copies

S. Congregazione dell'Indice dei libri proibiti di fine '50o', Il capitale culturale, 6 (2013), pp. 13-45, online: <http://riviste.unimc.it/index.php/cap-cult/article/view/40o>; it also includes an extensive bibliography on the topic. See also Flavia Bruni, 'The Book Inventories of Servite Authors and the Survey of the Roman Congregation of the Index in Counter-Reformation Italy', in Malcolm Walsby and Natasha Constantinidou (eds.), Documenting the Early Modern Book World: Inventories and catalogues in manuscript and print (Leiden: Brill, 2012), pp. 207-230.

4 Romeo De Maio, 'I modelli culturali della Controriforma: le biblioteche dei conventi italiani alla fine del Cinquecento', in Romeo De Maio, Riforme e miti nella chiesa del Cinquecento (Naples: Guida, 1973), pp. 365-381. See also Giovanna Granata, 'La più grande bibliografia nazionale della controriforma: il trattamento informatico dei dati dell'Inchiesta della Congregazione dell'Indice', in Roberto Rusconi (ed.) Il libro antico tra catalogo storico e catalogazione elettronica (Rome: Accademia nazionale dei Lincei, 2012), pp. 133-154.

5 Sacra rituum Congregatione eminentissimo et reverendissimo domino Card. Sancti Caesarei Panormitana beatificationis et canonizationis ven. servi Dei Aloysii La Nuza...positio super virtutibus (Rome: Tipografia Camerale, 1756), pp. 361-362; Antonino Mongitore, Bibliotheca sicula sive De scriptoribus siculis (Palermo: Diego Bua, 1707), vol. I, pp. 282-283; Jacobus Quétif \& Jacobus Échard, Scriptores Ordinis Praedicatorum recensiti (Paris: J.B. Christopher Ballard \& Nicolas Simart, 1719-1721), vol. II, pp. 210-211; Alessio Narbone, Bibliografia sicola sistematica o Apparato metodico alla storia letteraria della Sicilia (Palermo: Pedone Lauriel, 1850-1855), vol. III, p. 326; Giuseppe Mira, Bibliografia siciliana (Palermo: G.B. Gaudiano, 1875-1881), vol. I, p. 436; Pietro Manzi, La tipografia napoletana nel '50o. Annali di Giovanni Paolo Suganappo, Raimondo Amato, Giovanni de Boy, Giovanni Maria Scotto e tipografiminori, 1533-1570 (Florence: Olschki, 1973), p. 192. 
of a single edition, printed in Venice by Giordano Ziletti e soci in $1571 .^{6}$ In this paper, I am going to report on the Confessionario, a small, handy confessional manual in the Italian vernacular, which aimed to provide Catholic penitents with a detailed guide to making an accurate examination of their conscience and an effective confession of their sins.

As a result of the religious controversies of the sixteenth century, the Roman Church was persuaded of the need for strict discipline for the faithful under the control of the ecclesiastical institutions. The decrees of the Council of Trent restored the annual obligation of confession and communion, first laid down in 1215 at the fourth Lateran Council with the canon Omnes utriusque sexus. The correct administration of the reformed sacrament of penitence made it necessary to train confessors and instruct penitents: confessors were required to be able to examine and evaluate sins, and penitents to know how to recognize and confess their sins. To this end, a strategic role would be played in the post-Tridentine ministry by preaching, catechetical teaching and above all penitential literature. ${ }^{7}$ In the second half of the sixteenth century, Italian printers turned out many works with the dual function of offering collections of cases of conscience and providing confession manuals. Some of the texts that would be repeatedly published were traditional works, such as the many Summae - Pisanella, Angelica, Antonina, Aurea armilla, Silvestrina, Pacifica, Rosella - and the Confessionali (confession manuals), by Antonino da Firenze, Bernardino da Siena and Girolamo Savonarola. Alongside these works, which were translated into the Italian vernacular and duly abridged and adapted to the needs of the reformed Church, there were also published some fresh new texts, intended to help meet the new pastoral requirements. ${ }^{8}$

The high number of penitential works published in Italy before the midseventeenth century (surveyed by Miriam Turrini) can now be confirmed and enhanced by another, very different, survey carried out between 1597 and 1603 by the Sacred Congregation of the Index of Prohibited Books. ${ }^{9}$

The Confessionario by Girolamo da Palermo can rightfully be included among the texts produced in the sixteenth century as part of this wave of new

6 Edit16 CNCE 41212.

7 Pierre Michaud-Quantin, Sommes de casuistique et manuels de confession au moyen âge, $X I I^{e}-X V I^{e}$ siècles (Leuven: Nauwelaerts, 1962).

8 Roberto Rusconi, L'ordine dei peccati. La confessione tra Medioevo ed età moderna (Bologna: Il Mulino, 2002).

9 Miriam Turrini, La coscienza e le leggi. Morale e diritto nei testi per la confessione della prima età moderna (Bologna: Il Mulino, 1991), pp. 325-497. 
writings. Its editio princeps was long considered to have been the 1564 Neapolitan edition, printed by Giovanni Maria Scoto for the bookseller Gabriele Benzone. The work was first studied by Pietro Manzi, who in 1973 described the only copy known at the time, owned by the Vatican Library (Incun. VI.39, int. 18), along with further subsequent reprints. Manzi's record reads:

Confessionario raccolto da dottori catolici, per lo rever. Maestro Girolamo Panormitano del Ordine de Predicatori. Con privilegio. In Napoli. Appresso Gio. Maria Scotto. $1564.8^{\circ} .1^{\text {a }}$ edizione, cui seguirono numerose altre: Romae, 1575 , in $16^{\circ}$; Venetiis, Altobello Silicato, 1582, in 12 ${ }^{\circ}$; Panormi, Francisci Carrara, 1595, in $12^{\circ}$; Neapoli, Tarquinii Longi, 1611, in $8^{\circ}$; Maceratae, 1619, in $24^{\circ}$; Neapoli, Constantini Vitalis et Octavii Beltrami, 1641, in $8^{\circ}$; Vicentiae et Bassani, Jo. Ant. Remondini, 1670 , in $4^{\circ}$; e molte altre ancora.

[Confessionary compiled by the catholic doctors, for the rev. Master Girolamo Panormitano of the Order of Preachers. With privilege. In Naples. On the premises of Gio. Maria Scotto. 1564. $8^{\circ} .1^{\text {st }}$ edition, followed by many others: Romae, 1575, in $16^{\circ}$; Venetiis, Altobello Silicato, 1582, in 12 ; Panormi, Francisci Carrara, 1595, in $2^{\circ}$; Neapoli, Tarquinii Longi, 1611, in $8^{\circ}$; Maceratae, 1619, in 24'; Neapoli, Constantini Vitalis et Octavii Beltrami, 1641, in 8०; Vicentiae et Bassani, Jo. Ant. Remondini, 1670 , in $4^{\circ}$; and many others]. ${ }^{10}$

In 2006, the Italian national bibliography for the sixteenth century (Edit16) discovered another 1564 edition, produced in Brescia by Ludovico Sabbio for the book merchant Filippo De Salis; only two copies are known to date, one at the Collegio Nazareno, Opera Pia Library in Rome, and the other at the Malatestiana Library in Cesena. ${ }^{11}$ The title page of the edition printed in Brescia also carries information of fundamental importance on the editorial history of Girolamo da Palermo's work. It reads:

Confessionario raccolto da i dottori cattolici per il...p. maestro Girolamo panormitano. Nuouamente ristampato con alcuni aggiunti auisi \& osseruationi di molta importanza. [Confessionary compiled by the catholic doctors for...p. master Girolamo panormitano. Newly reprinted with added information and observations of great importance].

\footnotetext{
10 Manzi, La tipografia napoletana, pp. 191-192, drawing upon Quétif and Échard, Scriptores Ordinis Praedicatorum, vol. II, p. 211. For the 1564 Neapolitan edition of the Confessionario, see Edit16 CNCE 21304.

11 Edit16 CNCE 65596.
} 
This is crucial information: the edition printed in Brescia in 1564 presents itself to its readers as the latest, and updated, reprint of the work. We should, therefore, infer the existence of previous editions. This evidence is confirmed by seven editions in the RICI database printed before 1564 . The work seems indeed to have been repeatedly published in the years 1557-1563: in Venice, by Domenico and Giovanni Battista Guerra, in 1557; again in Venice, by an unknown printer, in 1558; in Naples, by Giovanni Maria Scoto, in 1560; in Brescia, by Tommaso Bozzola, in 1561; in 1562, in Venice, by Andrea Arrivabene, and in Bologna, by Pellegrino Bonardo; and once more in Venice, by Giorgio Cavalli, in $1563^{12}$

To date, however, there is no surviving copy of any of these editions. This absence raises a legitimate doubt whether such editions ever actually existed; could they rather be bibliographical ghosts that emerged from mistakes and misspellings in the Vatican inventories? This question needs to be posed, all the more so where the source only reports one single item for an edition. ${ }^{13}$ It is not difficult, however, to devise strategies to assess the relative reliability of individual records. The consistency of each bibliographic record with the recorded printer's years of activity, and the reliability of each list in more general terms, should be taken into consideration. Thus the 1562 Venetian edition by Andrea Arrivabene is included in the trustworthy list of Michel'Angelo, a Camaldolese monk of S. Biagio in Fabriano, who described a total of fifteen books with extreme care and accuracy. ${ }^{14}$

A close consideration of the publishing history of Girolamo da Palermo's work is fundamental in assessing the reliability of the records - which must always, in every case, be examined individually. Starting with the edition printed in Brescia in 1564, the work was edited by the Domenican Andrea Alchero from Materno, the Inquisitor of the Sant'Uffizio in Mantova, who died in $1574 .{ }^{15}$ Alchero prefaced Girolamo's text with some Avvisi of his own on sins and on methods of confession, without however adding his name to the titlepage. The title page also does not mention Alchero's dedicatory letter to Bishop Domenico Bollani, dated Brescia, 12 February $1564 .{ }^{16}$

12 Editions recorded in the RICI database аs вІв 8630; 41240; 12688; 47123; 61772; 13863; 40744 .

13 RICI вIB 8630; 41240; 47123; 61772; 13863; 40744.

14 'Jo, d. Michel'Angelo monaco camaldolese, de propria mano ho scritto quanto de sopra' ['I, d. Michel'Angelo Camaldolese monk, with my own hand did write the above']: Vatican Library, collection Vatican Latin (hereafter: VL) 11287, f. $55^{r-v}$.

15 Quétif and Échard, Scriptores Ordinis Praedicatorum, vol. II, p. 230.

16 Giovanni Pillinini, 'Bollani, Domenico', in Dizionario Biografico degli Italiani (Rome: Istituto dell'Enciclopedia italiana, 1969), vol. 11, pp. 291-293. 
This element of the paratext will turn out to be of crucial importance to understanding the significance of the Brescia edition as a starting point for all the following editions. In an intervention that had been agreed with Bollani, a firm supporter of the Tridentine reforms, a close collaborator of Carlo Borromeo and a diligent reformer of the Diocese of Brescia, Alchero reinforced the efficacy of the Confessionario with his additions to the edition that we should note, was published in the immediate aftermath of the Council of Trent. Girolamo's editorial guidance was fully in accord with the renewed emphasis on the discipline of the sacrament of penitence. Alchero reiterated this even in the notice 'To pious readers'. Thanks to this powerful endorsement, the Confessionario was regarded as a text of unquestioned orthodoxy and efficacy. It continued to be issued without further changes although, from the end of the 1560 s Alchero's name was increasingly added to the title page. New editions also include a further text entitled Modo breve \& risoluto diprepararsialla confessione [Brief and resolute way to prepare oneself for confession] by his fellow brother Desiderio Anichini from Verona along with some prayers to be recited before and after the sacraments. ${ }^{17}$

It is likely that this new presentation of Girolamo's text, enriched by these interventions by his two fellow brothers incorporated by all successive publishers, was the reason why the editions that preceded the 1564 Brescia edition had such a poor chance of survival. Many readers seemed more inclined to discard earlier editions in favour of these substantially enhanced texts. It is no surprise that the only copies to survive did so in the institutional collections surveyed for the Vatican investigation at the end of century. This pattern of institutional survival of redundant editions is not unusual. It is not therefore particularly surprising that we cannot find corroboration in surviving examples of the notitiae registered in the Vatican inventories. What this investigation certainly confirms is the real value of the RICI research project in reconstructing the publishing history of such forgotten bestsellers.

In the course of the decade after 1564 the title of the work took on its definitive form. De' Ferrari's 1572 Venice edition was entitled:

Confessionario, raccolto da i dottori cattolici per il r.p. maestro Girolamo Panormitano, dell'ordine de' Predicatori. Nuovamente ampliato d'alcuni utili avisi, \& osservationi, per frat'Andrea Alchero da Materno, dell'ordine predetto. Con la giunta di un Modo breve, e risoluto di prepararsi alla 
confessione. Raccolto dal r. padre fra Desiderio Anichino veronese, predicatore domenicano. Con alcune divote orationi di s. Agostino, di s. Bernardo, \& d'altri, alla confessione, \& sacratissima communione.

[Confessionary, compiled by the catholic doctors for the rev. father master Girolamo Panormitano of the Order of Preachers. Recently extended to include some useful information and observations by brother Andrea Alchero from Materno of the aforementioned Order. With the addition of a brief and resolute way of preparing oneself for confession. Compiled by rev. father fra Desiderio Anichino from Verona, Dominican preacher. With some devout prayers of St Augustine, St Bernard and others, for confession and for most holy communion.$^{18}$

Thus described, this work would continue to experience publishing success that the rarity of the surviving copies does not even lead one to suspect. Not even the most authoritative sources or modern-day repositories and catalogues - both traditional and online - provide adequate information regarding the real number of editions. With further additions by the Dominican Maurizio Gregorio from Cammarata, ${ }^{19}$ introduced in the 1611 Neapolitan edition of Tarquinio Longo, the Confessionario continued to be reprinted without interruption until the late seventeenth century in many parts of Italy: in Bologna, Brescia, Milan, Naples, Palermo, Rome, Turin, Venice, as well as new locations such as Ancona, L'Aquila, Macerata, Messina, Parma, Perugia and Vicenza, mainly with multiple editions in the same year and in the same town as is shown ad abundantiam in the RICI database for the sixteenth century.

The sustained importance of Girolamo's Confessionario is further corroborated by references in the works of contemporary authors such as Angelo Michele Castellari, master of Sacred Theology and rector of the parish church of St Matthew in Bologna, who in his Paragone della conscienza [Paragon of the Conscience] refers readers to the Confessionario for a detailed analysis of $\sin .{ }^{20} \mathrm{In} 1630$, persuaded of its utility for the evangelisation of the towns of the eastern Adriatic, the Sacra Congregatio de Propaganda Fide sponsored the publication of a translation of the work into Slavic under the direction of the Friar Minor of the Observance Stefano Mattei. Remondini republished the text in Vicenza and Bassano once again in 1670 and the printer Giuseppe Longhi re-edited it in Bologna in 1679, for reasons that he explained in the notice to readers:

18 (Venice: appresso Gabriele Giolito de' Ferrari, 1572). Edit16 CNCE 54962; USTC 833374.

19 Quétif and Échard, Scriptores Ordinis Praedicatorum, vol. II, pp. 566-568.

20 In Bologna: printed by Clemente Ferroni, at the request of pupils of the author, 1638 . 
Cortese lettore. Mi è venuto alle mani questo libretto già altre volte stampato in questa Città, e poi in Parma, l'anno 1577, a beneficio di quelle Anime, che bramano d'espurgare la propria coscienza da ogni macchia di peccato col Sagramento della Penitenza (mentre egli mostra chiaramente qual colpa sia mortale, e qual veniale) \& accioche un opera di tanto frutto non resti assorbita dall'oblivione, hò pensato di ritornarla alla luce per mezzo delle mie stampe. Tu cortese lettore contentati di trascorrerla con gl'occhi del corpo, perche son' sicuro, che da questa ne riceuerai gran' lume per vedere piu chiaro ciò che si deue mirare con la pupilla dell'Anima (f. A2r).

[Gentle reader. This booklet has come into my hands having already been published in this city, and then in Parma, in the year 1577, for the benefit of those Souls who crave to purge their conscience of every stain of sin with the Sacrament of Penitence (while it clearly shows which fault is mortal, and which venial) \& in order to prevent such a fruitful work from descending into oblivion, I have decided to restore it into the light by means of my printing presses. You, gentle reader, be happy to cast the eyes of your body over it, because I am sure that you shall receive great light from it to see more clearly what must be seen with the pupil of our Soul]. ${ }^{21}$

The heirs of Giacomo Amadio once again published the Confessionario in Vicenza in 1684 along with the Meditazioni by Luis de Granada and the Corona del rosario by Teseo Mansueti under the title Esercitio diurno del christiano, che desidera viuere, e morire in gratia del Signore, e salvar l'anima sua. Con alcune meditationi devote del r.p.f. Luigi Granata. Et insieme il Rosario della B.V. Maria, con altre pie, \& sante orationi. Et il copioso Confessionario del r.p. maestro Girolamo Panormitano dell'ordine de' predicatori [Daily practice of the Christian who wishes to live and die in the grace of the Lord, and to save his soul. With some devout meditations of rev. father fra Luigi Granata. Along with the Rosary of the Blessed Virgin Mary, with other pious and holy prayers. And the copious Confessionary of the rev. father master Girolamo Panormitano of the Order of Preachers].22

This was a remarkably successful book, massively popular with readers in Italy and beyond. In the sixteenth century alone, we can contrast the eight

21 Longhi's allusion to the 1577 Parma edition leads us to suppose that he still had access to a copy and adds further editorial evidence to our knowledge: to date, the RICI database for that year only records the editions of Perugia, Baldo Salviani (вІв 41186) and Venice, Al segno della Regina (вІв 59027).

The only copy is at the Biblioteca civica Bertoliana in Vicenza. 
editions specified by Miriam Turrini and the sixteen described in Edit16 almost all unique examples -, with the riches of the RICI database; albeit incomplete, this plausibly documents more than one hundred. ${ }^{23}$ The ownership of copies throughout Italy by friars and monks and in shared monastic libraries demonstrates the success of the work, otherwise unimaginable due to the high numbers of lost copies. ${ }^{24}$ This is yet further proof of the loss of data regarding book production of former times for certain types of text that experienced strong demand but were not necessarily conserved by readers. These clearly included penitential literature in the vernacular. And in the specific case of the Confessionario readers were not only men and women in cloisters but also, and to a large degree, clergy and lay penitents.

\section{Appendix}

\section{Editions of the Confessionario in the RICI database}

1557

Venice, Domenico and Giovanni Battista Guerra (BIB 8630, only copy at the nuns of S. Cassiano of Mortara, Pavia: no known copies survive).

$155^{8}$

Venice, s.n. (вів 41240, only copy ad usum of Thomas Venetus, Observant friar of S. Francesco della Vigna in Venice: no known copies survive).

1560

Naples, Giovanni Maria Scoto (BIв 12688, only copy ad usum of the Augustinian Aurelio di Belforte of the convent of S. Agostino at Monteleone: no known copies survive). 1561

Brescia, Tommaso Bozzola (BIB 47123, only copy ad usum of the Lateran Canon Leonardo da Brescia in the convent of S. Salvatore at Brescia: no known copies survive). 1562

Venice, Andrea Arrivabene (вІв 61772, only copy ad usum of the Camaldulese Michelangelo in the monastery of S. Biagio at Fabriano: no known copies survive);

23 Turrini, La coscienza e le leggi, pp. 427-428, nos. 851-858.

24 On the information potential of the Vatican corpus as a source see also Ugo Rozzo, 'Una fonte integrativa di Istc: l'inchiesta della Congregazione dell'Indice del 1597-1603', in Borraccini and Rusconi (eds.), Libri, biblioteche e cultura, pp. 215-250; Giovanna Granata, 'Le biblioteche dei religiosi in Italia alla fine del Cinquecento attraverso l'Inchiesta della Congregazione dell'Indice. A proposito di libri "scomparsi": il caso dei Francescani Osservanti di Sicilia', in Maria Grazia Del Fuoco (ed.), Ubi neque aerugo neque tinea demolitur. Studi offerti in onore di Luigi Pellegrini per i suoi settant'anni (Naples: Liguori, 2006), pp. 329-406. 
Bologna, Pellegrino Bonardo (вів 13863, only copy ad usum of Benedetto da San Colombano al Lambro in the convent of the Third Franciscan Order of S. Antonio abate at Piacenza: no known copies survive).

1563

Venice, Giorgio Cavalli (в гв 40744, only copy ad usum of the Observant Franciscus de Bagolino at the convent of S. Francesco in Padua: no known copies survive).

1564

Naples, Giovanni Maria Scoto for the bookseller Gabriele Benzone (not recorded in RICI; two copies are known to date, one at Vatican Library and the other at Biblioteca civica Bertoliana of Vicenza, CNCE 21304, USTC 833363);

Brescia, Ludovico Sabbio for the bookseller Filippo De Salis (not recorded in RICI; only two copies are known to date, one at the Collegio Nazareno, Opera Pia Library in Rome, and the other at the Malatestiana Library in Cesena, CNCE 65596, USTC 833364);

Brescia, Giovanni Battista Bozzola (вІв 76771, only copy ad usum of the Observant Tommaso da Rocca San Casciano in the friary of S. Francesco at Mirandola: no known copies survive).

1565

Venice, Giorgio Cavalli (вів 40138, only copy ad usum of the friar Paolo Refrigerio at the convent of S. Bartolomeo in Pesaro: no known copies survive). 1566

Venice, Giorgio Cavalli (в Ів 55086, only copy ad usum of the friar Antonio at the convent of S. Maria in Mombaruzzo: no known copies survive).

1567

Brescia, Vincenzo Sabbio forTommaso Bozzola (вів 76834, ad usum of Aurelio da Rimini in the friary of S. Maria delle Grazie and S. Bernardino at Rimini; single known copy survived at the Biblioteca Vallicelliana, Rome: CNCE 30107; USTC 833367, ill. 13.1); Brescia, Damiano Turlino (BIB 4680o, two copies ad usum of the monk Felice da Mantova in the cloister of San Benedetto Po and of the Regular Canon of the Lateran Benedetto da Brescia in the convent of S. Giovanni da Verdara in Padua: no known copies survive);

Naples, Giovanni Maria Scotto (в гв 9431, only copy ad usum of Pietro di Comiso in the cloister of S. Maria del Gesù in Modica: no known copies survive);

Parma, Seth Viotti (вів 19146, only copy at the abbey of S. Sepolcro in Astino, Bergamo: no known copies survive);

Venice, Stefano Zazzera (BIв 46150, only copy ad usum of Simone Zauli, Prior of the convent of S. Maria del Voto in Forlì: no known copies survive). 1568

Milan, Valerio and Girolamo Meda (вів 19658, copies at four religious libraries: no known copies survive); 
Venice, Andrea Muschio (вІв 48132, only copy ad usum of Agostino da Mantova at the convent of S. Bartolomeo in Mantua: no known copies survive).

1569

Ancona, Astolfo Grandi (вів 5391, only copy of the female monastery of S. Ponziano at Spoleto: no known copies survive);

Turin, heirs of Niccolò Bevilacqua (вІв 44972, ad usum of the friar Alessandro di Torino at the convent of the Minor Observant of Madonna degli Angeli in Cuneo: no known copies survive);

Venice, Andrea Muschio (в в 9926, copies at six libraries; single copy survived at the Biblioteca Ludovico II De Torres, Monreale: Ustc 500226).

1570

Venice, Domenico and Giovanni Battista Guerra (вІв 12215, copies of the convents of Venice, Trivolzio and Palermo: no known copies survive);

Venice, Giovanni Varisco (BIB 41067, copies at five libraries: no known copies survive).

1571

Brescia, Giacomo Britannico senior (вІв 59370, only copy at cenoby of the Cassinesi monks of S. Sisto in Piacenza: no known copies survive);

Venice, Domenico De Franceschi 'al segno della Regina' (вІв 48109, ad usum of the regular canon of the Lateran Giuseppe da Cremona at convent of S. Pietro in Ciel d'Oro in Pavia: no known copies survive).

1572

Naples, Orazio Salviani (вів 47330, ad usum of Alvise da Padova, regular canon of S. Maria della Carità in Venice: no known copies survive);

Venice, Domenico and Giovanni Battista Guerra (вІв 46453, ad usum of Giovanni Battista, Regular Canon of S. Leonardo in Verona: no known copies survive);

Venice, Gabriele Giolito De' Ferrari (в в 38983, ad usum of Modesto d'Ancona at the Franciscan convent of Castelfidardo, and of Paolo da S. Angelo, guardian of the friary of S. Angelo in Brolo; CNCE 54962, USTC 833374: no known copies survive); ${ }^{25}$

Venice, Grazioso Percacino (вів 38771 , two copies of the Camaldolesian hermits of Montecorona in the Caves of Massaccio, today Cupramontana, and of the Lateran Canons of S. Michele degli Scalzi in Pisa: no known copies survive);

Venice, heirs of Melchiorre Sessa (вів 6817, copies of the Franciscan friary of S. Maria della Grazia in Cassano Ionio, of the nuns of S. Cecilia in Città di Castello,

25 Edit16 dependent upon Salvatore Bongi, Annali di Gabriel Giolito de' Ferrari da Trino di Monferrato stampatore in Venezia (Rome: presso i principali librai, 1890-1895, 2 vols.). 
of the Camaldolese monks of S. Biagio at Fabriano and of the Capuchins of S. Antonio da Padova in Cortona: no known copies survive).

1573

Perugia, sine nomine (вІв 6269, copies in four libraries: no known copies survive);

Naples, Giuseppe Cacchi (вгв 77344, copy of the notary Geronimo Terrazzano of Pratola Peligna: no known copies survive);

Siena, sine nomine ( ВІ в 37115, ad usum of the Minor Observant Salvatore Scalandroni: no known copies survive).

1574

Rome, Giuseppe De Angelis (ві в 6270, copies ad usum of the Lateran canon Cristoforo da Piacenza at the convent of S. Maria in the Isole Tremiti, and in the library of S. Francesco in Assisi: no known copies survive).

1575

Rome, Giuseppe De Angelis (в гв 489oo, ad usum of Gio. Battista di Casale at the friary of S. Bernardino in Alessandria; single surviving testimony at the Biblioteca Casanatense in Rome: CNCE 65834; USTC 833376);

Rome, Giovanni Gigliotti (В Ів 15551, ad usum of the provincial minister Observant Francesco Crociani da Sartiano in the convent of the ss. Trinità in S. Fiora: no known copies survive);

Milan, Paolo Gottardo Da Ponte (BI в 19670, three copies at the convents of S. Maria in Monteveglio, of S. Giovanni Battista in Bagnocavallo, of S. Alessandro in Zebedia of Milan; only surviving copy at the Biblioteca comunale Manfrediana in Faenza: CNCE 24441; USTC 833377);

Brescia, Vincenzo Sabbio (вів 66848, single copy recorded at the convent of S. Daniele in Monte of Padua: no known copies survive);

Perugia, sine nomine (вІв 22648, ad usum of Antonio da Osimo in the friary of S. Francesco in Fermo: no known copies survive);

Venice, Domenico and Giovanni Battista Guerra (вІв 8394, copies at eleven convents: no known copies survive).

1576

Bologna, Giovanni Rossi (BIB 59307, copies at six libraries; only known surviving copy at the Biblioteca provinciale dei Frati minori dell'Emilia in Bologna: CNCE 53075; USTC 833379);

Brescia, appresso i Turlini (not recorded in RICI; single known surviving testimony at Biblioteca Ambrosiana, Milan: CNCE 68524; UstC 833383);

Venice, Gabriele Giolito De' Ferrari (вів 15223, two copies at the friary of S. Cataldo in Corato and of S. Maria Maddalena in Mirandola; CNCE 21305; USTC 833381: no known copies survive);26

26 Edit16 dependent upon Bongi, Annali di Gabriel Giolito de’ Ferrari. 
Domenico and Giovanni Battista Guerra (вІв 64003, ad usum of father Ippolito in the convent of S. Maria Maddalena in Treviso: no known copies survive).

1577

Perugia, Baldo Salviani (в вв 41186, copies at four libraries: no known copies survive);

Venice, in Frezzeria 'al segno della Regina' (вІв 59027, copy of an uncertain monastery of the Camaldolese monks; only known surviving copy at the Biblioteca comunale diocesana S. Benedetto, Norcia: CNCE 69996; USTC 833385).

1579

Siena, sine nomine (в Ів 7763, copies of the Capucins of S. Antonio da Padova in Cortona and of the nuns of S. Maria Maddalena at L'Aquila: no known copies survive);

Brescia, Giacomo Britannico junior (BI B 75851, copy of the Capucins of S. Geminiano at Busseto: no known copies survive);

Venice, Andrea Muschio (вів 10536, copy of the Capucins of Santo Spirito at Rogliano: no known copies survive);

Venice, in Frezzeria, 'al segno della Regina' (вів 43452, ad usum of the Friar Minor Simone di Calitri at Nocera and of the Cassinese monk Gio. Angelo Faiella: no known copies survive).

1580

Venice, Domenico and Giovanni Battista Guerra (ВІв 21368, ad usum of Lucrezio da Milano of the Servants of Mary in Milan: no known copies survive). 1581

Rome, Domenico Piolato (вгв 22873, ad usum of Antonio Maria da Macerata at the friary of S. Francesco in Macerata, and of Fulgenzio da Cremona of the friary of S. Maria della Pace in Rome: no known copies survive);

Venice, Domenico Cavalcalupo (в Ів 9641, copies at six convents: no known copies survive);

Venice, 'al segno della Regina' (в в в 14973, ad usum of the friar Gregorio di Casalnuovo at the convent of S. Andrea in Barletta: no known copies survive);

Bologna, Giovanni Rossi (B I B 49167, ad usum of the father Gio. Battista da Fontaneto at the friary of S. Bernardino in Alessandria: no known copies survive).

1582

Naples, Orazio Salviani (в в 64461, copy of the Capucins of Caltagirone: no known copies survive);

Venice, heirs of Luigi Valvassori 'al segno dell'Ippogrifo' (в Ів 31745, copy of the Cassinese monastery of S. Pietro di Modena: no known copies survive);

Altobello Salicato (вІв 9137, copies at six libraries: no known copies survive). 1583

Venice, presso i Gioliti (вІв 50791, ad usum of the Cassinese cleric Ottavio Cecere and of the Coronese hermits of S. Maria dell'Incoronata at Benevento; only known surviving copy at the Biblioteca del Seminario vescovile of Padua: CNCE 65833; ustC 833387); 
Venice, heirs of Francesco Rampazetto (BIB 25553, three copies at the convents of Montecchio, Acqui and Bologna: no known copies survive);

Venice, Altobello Salicato (ві в 64833, copy of the Capucins of Noto: no known copies survive).

1584

Rome, Vincenzo Accolti (вів 38113, ad usum of Francesco da Parrano at S. Maria della Fratta of Umbertide, of Giacomo Criale at Castellabate and of the nun Caterina Pelletta in the Annunziata of Asti: no known copies survive);

Brescia, Policreto Turlino (вів 25968, copy of the monastery of S. Maria di Vallombrosa at Regello: no known copies survive);

Brescia, sine nomine (вів 48610, ad usum of the canons Andrea da Brescia at S. Lazzaro of Rimini and Giulio da Bergamo at S. Leonardo of Verona: no known copies survive);

Venice, Bernardo Giunta (BI B 17588, ad usum of Paolo di Patti at S. Maria del Gesù of Patti; a copy of this edition is likely to be that at Biblioteca comunale Sperelliana, Gubbio, with incomplete title page missing the date: CNCE 21303; USTC 833357);

Venice, Fabio e Agostino Zoppini (вів 70645, ad usum of the canon Illuminato da Brescia at S. Lazzaro of Rimini: no known copies survive).

1585

Brescia, Vincenzo Sabbio (вів 64394, copy of the Capucins of Malta: no known copies survive);

Venice, Fabio e Agostino Zoppini (в I в 25379, ad usum of Antonio da Montecchio at Treia and of Cassinese monk Pietro del Mastro: no known copies survive);

Venice, Francesco Patriani 'all'insegna dell'Ercole' (вів 53116, ad usum of the friars Michele, at S. Maria delle Grazie in Arzignano, and Francesco da Imola, at S. Apollinare in Ravenna: no known copies survive). 1586

Rome, Vincenzo Accolti (edition not recorded in RICI; single known surviving copy at the Biblioteca Nazionale Centrale of Rome: CNCE 23322; USTC 833390);

Turin, heir of Niccolò Bevilacqua (В Ів 24844, three copies at the Observants of Busca and of Asti and at the Barnabites of Novara: no known copies survive);

Palermo, Giovanni Francesco Carrara (вів 23515, copies at three libraries of the Conventual Friars of Sicily; CNCE 56990; USTC 833389: no known copies survive); ${ }^{27}$

27 Edit16 dependent upon Carlo Pàstena, Angela Anselmo, Maria Carmela Zimmardi, Bibliografia delle edizioni palermitane antiche. I: Edizioni del XVI secolo (Palermo: Regione siciliana, Assessorato regionale dei Beni culturali e ambientali e della pubblica istruzione, 1998) (hereafter: BEPA), no. 186. 
Florence, Giorgio Marescotti ( in Montecelso at Siena: no known copies survive);

Venice, Giovanni Varisco \& с. (в Iв 54966, copies at the Minors Friars of S. Maria di Mombaruzzo in Asti, and at the Coronese hermits of S. Maria dell'Incoronata of Benevento: no known copies survive);

Venice, Fabio and Agostino Zoppini (вІв 31741, copy at cenoby of the Cassinese monks of S. Pietro in Modena: no known copies survive);

Venice, Domenico and Giovanni Battista Guerra (B Iв 25880, copy of the Minors Friars of S. Francesco of Sciacca: no known copies survive).

1587

Venice, Domenico and Giovanni Battista Guerra (вІв 9233, ten copies distributed in the cloisters of several religious Orders: no known copies survive);

Rome, Vincenzo Accolti (в в в 38171, ad usum of the monk Francesco Antonio Cepolla at Castellabate: no known copies survive);

Naples, Orazio Salviani (в вв 12622, two copies ad usum of the friar Pietro at S. Maria delle Grazie a Barisciano in Abruzzo and of the monk Giovanni Battista Vecchi in the monastery of Montevergine at Mercogliano: no known copies survive).

1588

Brescia, heirs of Giacomo Britannico (в I в 38392, copies at the Minors Friars of S. Maria di Campagna in Piacenza and at the Celestine monks of S. Maria Nova in Magenta: no known copies survive);

Vicenza, Agostino Dalla Noce (вIв 40472, four copies at the convents of Naples, Vicenza, Padua and Venice: no known copies survive);

Messina, Fausto Bufalini (BIB 15668, , copies at five libraries: no known copies survive);

Naples, Orazio Salviani (в гв 38567 , three copies distributed in the cloisters of the Campania: no known copies survive).

1589

Bologna, Giovanni Rossi (в Ів 37970, ad usum of the Observant friar Pietro da Firenze: no known copies survive);

Bologna, Pellegrino Bonardo (вгв 61642, library of the Canons of S. Maria fuori porta in Lucca: no known copies survive);

Venice, Giovanni Fiorina (вІв 15710, ad usum of Giulio at the convent of the ss. Trinità at Santa Fiora in Tuscany: no known copies survive);

Venice, Giacomo Cornetti (вів 45629, ad usum of the monk Giulio Piroscia at the Montevergine abbey: no known copies survive);

Naples, Orazio Salviani (вів 45361 and 64684, copies at the Verginian monastery of Salerno and Mercogliano and in the library of the Capucins of Piazza Armerina in Sicily: no known copies survive). 
1590

Naples, Giovanni Battista Cappelli (вів 45012, copies in three libraries of Aversa, Castellabate e Pavia: no known copies survive);

Naples, Giovanni Giacomo Carlino (вів 29277, ad usum of the Augustinian friar Gregorio da Fossato: no known copies survive).

1591

Palermo, Giovanni Battista Maringo (в в 15673, ad usum of Leone di Scicli in the friary of S. Maria del Gesù at Salemi: no known copies survive);

Venice, Giovanni Fiorina (вIв 54107, two copies in the libraries of Acqui and Genova, a copy in the possession of the notary Giovanni Vincenzo Rescigno: no known copies survive);

Venice, Domenico Imberti (вІв 32888, two copies of the books of the Minor Observant Francesco Ramucci and of the rich library of the Camaldolensian Montecorona abbey at Monteconero of Ancon: no known copies survive). 1593

Naples, Giovanni Battista Cappelli (вів 52891, ad usum of the father Cassinese Marco Marotta: no known copies survive).

1595, year of Girolamo's death:

Venice, brothers Guerra (вів 8265, ad usum of the Cassinese nun Prospera Vittoria of S. Teodata in Pavia: no known copies survive);

Rome, sine nomine (в Ів 30426, at the Franciscan convent of Città Sant'Angelo: no known copies survive);

Palermo, Giovanni Francesco Carrara (edition not recorded in RICI; CNCE 56991; USTC 833392: no known copies survive). ${ }^{28}$

1596

Naples, sine nomine (в вв 61191, ad usum of the Augustinian friar Michele di Marcellinario at the convent of S. Floro in Nicastro: no known copies survive).

1597

Palermo, Giovanni Battista Maringo (в І в 15111, four copies; CNCE 56992; USTC 833393: no known copies survive); ${ }^{29}$

Messina, Pietro Brea (вів 9629, three copies in the hands of Minors Friars of the Sicilian convents: no known copies survive);

L'Aquila, Lepido Faci (вІв 25417, ad usum of the father confessor Arcangelo Barasca in the convent of Saltareccio at Fermo: no known copies survive);

28 Edit16 dependent upon BEPA, no. 187.

29 Edit16 dependent upon BEPA, no. 188. 
Venice, Marco Claseri (вІв 14433, two copies ad usum of the friars Arcangelo Borsari da Reggio at the convent of S. Maria degli Angeli in Vicenza and Francesco da Budua at the friary of S. Maria in Piove di Sacco: no known copies survive).

1598

Venice, Marco Claseri (В в 31215, ad usum of the friar Giacinto da Rimini at S. Maria in Porto of Ravenna, of Marsilio Barbante da Fabriano at S. Giovanni in Jesi and a copy at the library of the Coronese abbey of Rua, Padua: no known copies survive).

1599

Venice, Altobello Salicato (в Ів 55822, ad usum of Antonio da Ferrara in the convent of S. Sebastiano in Venice: no known copies survive).

1600

Rome, Guglielmo Facciotti (вIв 32057, a copy at the library of the Franciscan convent of S. Francesco a Ripa in Rome: no known copies survive).

Unidentified editions due to incomplete or wrong citation in inventories:

[S.l., s.n., s.a.] (вгв 53801, copies ad usum of the Cassinese cleric Agostino Marotta and in the Augustinian library of Sessa);

[S.l., s.n., s.a.] (вІв 65531, only copy in the Augustinian library of Capua);

[S.l., s.n.], 1526 (вІв 29086, only copy in the library of the Conventual Friars at Campli);

Venice, [s.n., s.a.] (вів 64555, only copy ad usum of Sergio, lay brother at Camaldolese monastery of S. Giovanni Battista, Bagnacavallo);

Rome, Guglielmo Facciotti, [s.a. ${ }^{30}$ (вІв 16350, only copy ad usum of the friar Gabriele Bartoli in the cloister of S. Antonio di Padova in Tivoli);

[Venice], Giorgio Cavalli, [s.a. ${ }^{31}$ (в Ів 10137, copies at the Capucins of S. Maria delle Grazie of Montalto Offugo, Cosenza and ad usum of Arcangelo di Cammarata at Observant convent of S. Maria del Gesù in Cammarata);

Naples, Bartolomeo Vassallo, [s.a.] (в в в 40563, at the Capucins of S. Maria Lauretana at Itri); ${ }^{32}$

$30 \quad$ Likely 1600 , see below, в в 32057 .

31 Perhaps one of the editions listed below: 1563 (в гв 40744), 1565 (вів 40138), 1566 (в гв 55086).

32 Another copy sine anno is listed among the books of donna Lucretia Galteri di Castellabate (VL 11266, f. 520r), not registered in the RICI database yet. This edition is likely to have been printed in the late 1590s, perhaps 1597, with other books printed by Bartolomeo Vassallo, an obscure printer completely unknown to Edit16. On Bartolomeo Vassallo see Giuseppina Zappella, 'Alla ricerca del libro perduto', in Vincenzo De Gregorio (ed.), Bibliologia e critica dantesca: saggi dedicati a Enzo Esposito, I: Saggi bibliologici (Ravenna: Longo, 1997), pp. 243-293, at pp. 255-256; Carmela Compare, 'Libri di donne e libri di monache alla fine del Xvi secolo', and Sara Cosi, 'I libri dei sudditi: Mercogliano, feudo di 
Venice, Andrea Arrivabene, $1502^{33}$ (вІв 40365, only copy ad usum of Paulus de Salocio at Observant friary of S. Francesco della Vigna in Venice);

Venice, Domenico and Giovanni Battista Guerra, $1509^{34}$ (вІв 25459, only copy ad usum of the Observant Angelo di Cammarata in the cloister of S. Maria del Gesù at Cammarata).

Montevergine', in Borraccini and Rusconi (eds.), Libri, biblioteche e cultura degli Ordini regolari nell'Italia moderna, pp. 583-622, p. 598; and pp. 623-657, pp. 641-642.

33 Likely to be a mistake for 1562 , see below, вів 61772 .

34 The Guerra brothers started their printing activity in the late sixteenth century and reprinted the Confessionario many times: see above. 


\section{CONFESSIONARIO $Z$ RACCOLTO DAI Dottori Catolici.}

- PER IL R. P. MÁESTRO Girolamo Panormitano, dell'Ordine de Predicatori.

Nuouamente ampliato dı alcuni auifi, \& offeruationi d'importanza, per $\mathrm{F}$. Andrea Alchero da Materno, dell'ordine predetto .

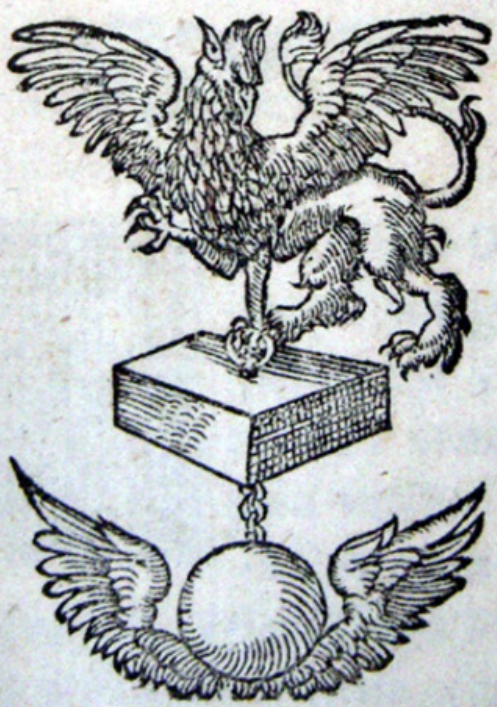

IN BRESCIA,

Appreffo Vincenzo di Sabbio. M. D. LXVII. f. Andrea Alchero da Materno (Brescia: Vincenzo Sabbio for Tommaso Bozzola, 1567), title page

(c) Biblioteca Vallicelliana, Rome [S.Borr.C.V.20o.2]. 